\title{
Integrasi Pembelajaran Matematika Problem Based Learning dengan Teknologi Informasi dan Komunikasi
}

\author{
M. Taufik Qurohman ${ }^{1 *}$, Muchamad Sobri Sungkar ${ }^{1}$ \\ 1 Politeknik Harapan Bersama. Jl. Mataram No.9 Pesurungan, Kota Tegal ,Indonesia. \\ *Corresponding Author. E-mail: taufik.qurohman@poltektegal.ac.id
}

Received : 25-08-2018; Revised : 31-08-2018; Accepted : 14-09-2018

\begin{abstract}
Abstrak
Metode Pembelajaran inovatif metode problem based learning (PBL) terintegrasi teknologi informasi dan komunikasi diharapkan mampu memberikan solusi untuk meningkatkan daya tarik dan kemampuan pemecahan masalah. Tujuan penelitian mengoptimalisasi Metode Pembelajaran inovatif PBL dengan diterapkan teknologi informasi dan komunikasi sehingga terjadi peningkatan kemampuan pemecahan masalah dari Metode Pembelajaran yang dihasilkan. Penelitian ini merupakan Classroom Action Research ada 4 langkah : Perencanaan, Tindakan, Observasi dan Refleksi. Hasil penelitian Penerapan metode pembelajaran Problem Based Learning Terintegrasi TIK pada matakuliah matematika terapan 2 adalah : (1) hasil sebaran kuisioner minat mahasiswa pada pembelajaran PBL terintegrasi TIK setelah diberi perlakuan dengan prosentase awal dengan menggunakan nilai mahasiswa disemester sebelumnya yang sebesar 22,87 \% meningkat menjadi 89,00 \% pada siklus II, (2) Meningkatkan aktifitas belajar mahasiswa, hal ini dapat dilihat dari prosentase aktifitas mahasiswa di siklus I dengan tingkat prosentase $64 \%$ dengan lembar observasi tergolong cukup aktif, dan pada siklus II sebesar 76 \% yang masukl kategori aktif, (3) meningkatkan prestasi, aktifitas, dan minat belajar mahasiswa yang terlihat dari perolehan nilai rata - rata mahasiswa pada siklus I sebesar 66,88 dan dengan ketuntasan belajar mahasiswa 56\%. Nilai rata - rata mahasiswa di siklus II sebesar 78,27 dan ketuntasan belajar mahasiswa adalah 100\%.
\end{abstract}

Kata kunci : Pembelajaran Matematika, Problem Based Learning ,TIK

\begin{abstract}
Problem-based learning Metode Pembelajaran that is integrated with information and communication technology is expected to be able to provide solutions to increase attractiveness and problem-solving abilities. The purpose of study optimizes PBL Metode Pembelajaran by applying information and communication technology so that there is an increase in the problemsolving ability of the resulting Metode Pembelajaran. Experiments were carried out to get the best Metode Pembelajaran test with indicators of increasing achievement and problem-solving abilities. This research is a Classroom Action Research there are 4 steps: Planning, Action, Observation, and Reflection. The results study The application of contextual learning in applied mathematics courses 2 are: (1) the results of the distribution of questionnaires of students' interest in learning integrated problem based learning ICT before and after being given a learning treatment Problembased learning has changed from cycle I which is $22.87 \%$ increased to $8900 \%$ in cycle II, (2) Increasing student learning activities, this can seen from the percentage activity in the first cycle of $64 \%$ classified as quite active, and in the second cycle by $76 \%$ and classified as active, (3) improving achievement, activity, and interest in student learning. This increase can be seen by the acquisition of the average of students in the first cycle of 66.88 and with student learning completeness of 56\%. The average value in cycle II is 78.27 and the student learning completeness is $100 \%$.
\end{abstract}

Keywords : Mathematics Learning, Problem Based Learning, ICT 


\section{PENDAHULUAN}

Pemerintah Indonesia melalui Direktorat Pendidikan Sekolah Menengah telah membangun dan mengembangkan program Pengembangan infrastruktur Teknologi informasi dan komunikasi (TIK) yang mengkoneksikan secara online sekolah, dinas, dan perguruan tinggi diseluruh Indonesia (Marzal, 2013). Sehingga dalam proses penelusuran data dan monitoring dinas terkait dapat berjalan dengan baik, dan proses kebiajakan juga cepat terlaksana. Begitu juga dalam proses pembelajaran yang digunakan pada level pendidikan dasar sampai perguruan tinggi sangat relevan dengan pembelajaran yang harus selalu ada inovasi dalam prosesnya sangat relevan dengan menggunakan TIK (Fitriyadi, 2012). Sehingga di harapkan proses pembelajaran menyenangkan dan tidak membosankan serta dapat memacu prestasi mahasiswa.

Berdasarkan observasi awal terhadap mahasiswa prodi DIII Teknik Mesin Khususnya matakuliah Matematika Terapan 2 terlihat dari nilai ujian masih rendah, sehingga menjadi masalah yang harus segera di selesaikan dengan memadukan Metode Pembelajaran pembelajaran dan IPTEK khususnya aplikasi TIK yang sudah menjadi solusi untuk memaksimalkan proses dan hasil pembelajaran pada perkuliahan matematika.

Problem Based Learning (PBL) adalah metode pembelajaran yang selalu dimulai dan pada masalah yang terkait sangat fokus (Fatimah, 2012). Didalam PBL mahasiswa relative aktif didalam 4-5 Orang (kelompok) dan mahasiswa mengidentifikasi sehingga meraka mengerti dan selalu berusaha untuk memecahkan masalah. Disini peranan Dosen adalah untuk memudahkan proses kelompok dan proses belajar. Sedangkan Pemecahan masalah adalah Penyelesaian pemecahan terkait pembelajaran yang unik karena peserta didik/mahasiswa diminta merangkai pemahaman mereka sendiri dengan permasalahan yang otentik dimana dikembangkan secara mandiri (Romadhon \& Qurohman, 2017).

Penelitian ini dilakukan dengan melihat perkembangan dan kemajuan teknologi maka perlu dilakukan penelitian yang berbasis teknologi dan mengedepankan Pemecahan Masalah. Sehingga proses pembelajaran dilakukan untuk menganalisis tingkat pemahaman dan pemecahan masalah terhadap matakuliah matematika terapan 2 dengan menerapkan Prolem Based Learning sebagai Metode Pembelajaran yang terintegrasi dengan Teknologi Informasi dan komunikasi. Sehingga dari penelitian yang dilaksanakan diharapkan dapat memberikan perubahan positif untuk perubahan tingkat prestasi dan pemecahan masalah matematika khususnya pada matakuliah matematika terapan 2 Prodi DIII Teknik Mesin.

PBL sebagai Metode Pembelajaran pembelajaran memiliki perbedaan dengan Metode Pembelajaran lainnya ini terlihat dari proses pembelajarannya, yang selalu di awali dan fokus pada masalah. Pada proses pembelajaran aktif dalam kelompok yang terdiri dari 4-5 orang dan merefleksi apa yang mereka pahami terkait dengan materi yang diberikan (Masitoh \& Fitriyani, 2018). Adapun penelitian sebelumnya yang telah menggunakan PBL sebagai metode pembelajaran diantaranya PBL mempengaruhi; minat belajar dan pemahaman, berpikir kritis, komunikasi matematis dan pemecahan masalah, serta Self Eficacy (Muhson, A., 2009; Wulandari, N. and Damris, M., 2011; Fatimah, F., 2012; Sariningsih, R. and Purwasih, R., 2017)

Pembaharuan dalam penelitian ini adalah memadukan antara Pembelajaran yang berbasis TIK merupakan sebuah proses pembelajaran yang dalam prosesnya melibatkan TIK sebagai sarana dalam mencapai tujuan proses perkuliahan khusus. Dan penelitian sebelumnya yang telah 
menggunakan media TIK dalam pembelajaran diantaranya TIK dapat meningkatkan; hasil pendidikan jarak jauh, pemahaman, kualitas pembelajaran (Hardhono, A.P., 2002; Nuraeni, N., Fitrajaya, A. and Setiawan, W., 2010; Ismaniati, C., 2010).

TIK sendiri tidak hanya segala hal yang terkait dengan komputer dan internet melainkan media dan komunikasi lain video radio kaset audio yang berbasis dan terintegrasi (Akhmadi \& Qurohman, 2018). Sehingga terlihat TIK pada beberapa metode pembelajaran ,strategi pembelajaran yang dibuat oleh dosen sangat diperlukan (Nasir \& Hasmar, 2018). Dan sumber belajar dalam proses perkuliahan sangat diperlukan sehingga perlu dilakukan untuk penelitian untuk melihat prosentase keberhasilan dan perbandingannya dalam sebuah penelitian tindakan kelas terkait dengan metode pembelajaran yang terintegrasi TIK.

\section{METODE}

Pada penelitian yang dilakukan karena jenis penelitian ini adalah eksperimen maka terdapat beberapa tahapan yang digunakan seperti yang ditunjukan pada Gambar 1:

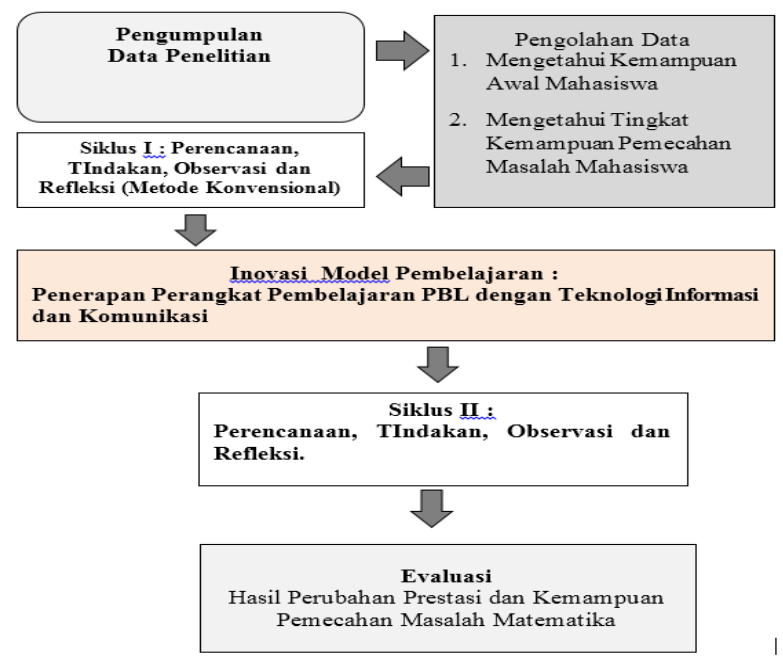

Gambar 1. Tahapan dalam penelitian
Pada Gambar 1 kegiatan pada penelitian yang akan dilaksanakan dengan langkah sebagai berikut:

\section{a. Pengumpulan Data Penelitian}

Pengumpulan data dilakukan pada data yang diproses dan mencari data yang tersedia, serta mencari data tambahan.

\section{b. Pengolahan Data}

Data awal diolah untuk mengetahui kemampuan awal mahasiswa dan tingkat kemampuan pemecahan masalah matematika.

\section{c. Silkus I}

Proses pembelajaran dengan Metode Pembelajaran kovensional melalui proses : Perencanaan, TIndakan, Observasi dan Refleksi

\section{d. Inovasi Metode Pembelajaran \\ Penerapan Perangkat Inovasi Metode Pembelajaran Pembelajaran.}

\section{e. Siklus II}

Proses pembelajaran dengan inovasi Metode Pembelajaran pembelajaran integrasi Problem Based Learning dengan Teknologi Informasi dan Komunikasi, melalui proses : Perencanaan, TIndakan, Observasi dan Refleksi

\section{f. Evaluasi}

Merupakan hasil perbandingan evaluasi antara siklus I dan siklus II

Metode eksperimen digunakan metode yang digunakan pada penelitian ini dan merupakan kegiatan utama. Pada penelitian ini diusulkan sebuah inovasi Metode Pembelajaran untuk menghasilkan Metode Pembelajaran terbaik untuk mengukur tingkat prestasi dan kemampuan pemecahan masalah matematika. Desain penelitian digambarkan pada Gambar 2: 


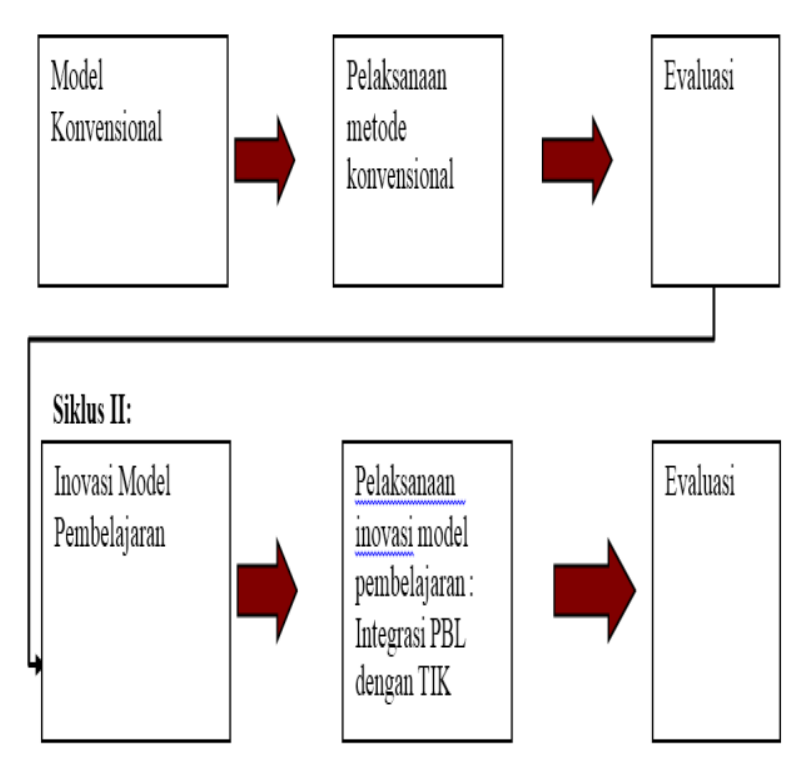

Gambar 2. Desain Penelitian

Gambar 2 memperlihatkan pada pelaksanaan penelitian komparasi dengan melihat perubahan hasil evaluasi dari Siklus yang telah dilaksanakan, kemudian dapat di simpulkan Metode Pembelajaran inovasi pembelajaran lebih baik atau sebaliknya.

\section{Analisis Data}

Analisis data di tampilkan dalam bentuk tabel nilai setelah dilakukan pengambilan data. Proses analisa yang digunakan adalah kuantitatif, jadi dengan melihat nilai hasil belajar serta nilai rataratanya kemudian menghitung tingkat ketuntasannya dalam bentuk prosentase dimana dibandingkan dengan nilai kemampuan awal mahasiswa pada semester sebelumnya. Demikian juga untuk hasil penskoran observasi kemampuan pemecahan masalah, datadata yang diperoleh dibuat dalam tabulasi, dilakukan penilaian dan dihitung persentase skornya. Secara kualitatif, dari hasil pengamatan terhadap pelaksanaan pembelajaran dideskripsikan untuk memberikan gambaran secara jelas.

\section{HASIL DAN PEMBAHASAN}

Deskripsi hasil penelitian dilakukan dengan menggunakan metode pembelajaran problem based learning terintegrasi TIK untuk mendapatkan hasil dari Metode Pembelajaran inovasi pembelajaran yang disulkan. Berdasarkan hasil yang telah didapatkan pada ekperimen dari Metode Pembelajaran inovasi pembelajaran sebagai berikut:

\section{a. Siklus I}

Untuk mendapatkan Metode Pembelajaran inovasi pembelajaran yang diharapkan, dilakukan dengan proses penentuan nilai prestasi mahasiswa.

\section{1) Rencana Tindakan}

Tindakan khususnya dalam perencanaan pada PTK Siklus I sbb:

a) Pembuatan perangkat belajar berupa Rencana Pembelajaran Semester (RPS), RPP soal-soal evaluasi dan lembar observasi.

b) Koordinasi dengan Dosen lain yang bertindak sebagai pengamat (Observer) dalam proses pembelajaran

c) Melakukan evaluasi berupa tes tertulis/uraian untuk mengetahui kemampuan mahasiswa pada matakuliah matematika terapan 2 materi turunan.

\section{2) Pelaksanaan Kegiatan}

Pada siklus I wujud pelaksanaan tindakan pembelajaran yang telah

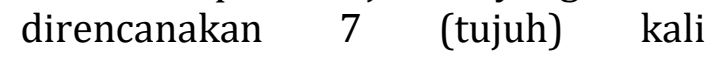
pertemuan selama $2 \times 50$ Menit dan dilanjutkan dengan evaluasi 60 menit. Adapun tindakan dosen yang dilakukan adalah sebagai berikut :

a) Dosen memberikan apersepsi dan motivasi disetiap awal pertemuan serta mengingatkan akan hal - hal yang berkaitan dengan matakuliah yang akan diajarkan.

b) Dosen memberikan beberapa pertanyaan kepada mahasiswa dikelas untuk mengetahui pengetahuan awal mahasiswa mengenai matakuliah matematika 
terapan 2, kemudian menghubungkan dengan kehidupan sehari - hari dan membimbing mahasiswa untuk mengkontruksikannya.

c) Mahasiswa mendiskusikan hasil persoalan matematika terapan dalam kelompok yang telah ditentukan. Mereka secara bergantian menjelaskan alurnya, memberikan contoh soal beserta penyelesaiannya, dan kelompok yang lain menanggapi.

d) Mahasiswa menyelesaikan serta mendiskusikan Lembar Kerja yang diberikan oleh dosen, dan mengerjakan secara mandiri. Kemudian dosen memberikan bimbingan kepada mahasiswa jika menemukan kesulitan.

e) Dosen membimbing mahasiswa untuk menyimpulkan materi yang telah diperoleh pada setiap akhir pertemuan.

f) Pada pertemuan selanjutnya mahasiswa mengumpulkan hasil diskusi dan pemecahan masalahnya pada matakuliah matematika terapan 2.

g) Pada akhir siklus I dilakukan evaluasi untuk mengukur dan mengetahui kemampuan mahasiswa.

\section{3) Observasi dan Evaluasi}

Berdasarkan hasil pengolahan keaktifan mahasiswa dalam proses pembelajaran masih perlu dilakukan perbaikan terutama keberanian mengeluarkan pendapat, mengaitkan materi matakuliah matematika terapan 2 dengan kehidupan nyata. karena terdapat perbedaan kemampuan karakteristik diantara mahasiswa yang satu dengan yang lainnya. Motivasi dosen dalam membangkitkan motivasi perlu dikembangkan lagi. Selanjutnya keseluruhan aktifitas mahasiswa pada siklus I terekam pada lembar observasi dan nantinya akan menjadi catatan tersendiri bagi dosen didalam melakukan perbaikan dan inovasi pembelajaran. Hasil evaluasi siklus I memberikan kesimpulan belum tercapainya ketuntasan pada matakuliah matematika terapan materi turunan.

4) Refleksi

Releksi diperoleh dari evaluasi mahasiswa pada proses siklus pertama yang belum mencapai ketuntasan, maka akan dilakukan perbaikan - perbaikan. Baik dari strategi pembelajaran yang perlu dimodifikasi sehingga terdapat inovasi Metode Pembelajaran pembelajaran melalui bentuk soal latihan yang dikerjakan mahasiswa.

Terkait dengan ketidaktuntasan mahasiswa pada siklus I ditemukan adanya beberapa faktor diantaranya adalah kelemahan mahasiswa dalam menguraikan soal integral dalam turunan yang bersifat lebih dari satu proses. Serta kurangnya media pembelajaran dan buku materi perkuliahan.

Maka sebagai bentuk refleksi pada siklus I tersebut antara peneliti dan observer melakukan koordinasi dan sepakat menerapkan media pembelajaran dan modul sebagai usaha khususnya terkait dengan soal bentuk terapan.

Berdasarkan hasil evaluasi dan observasi terhadap perlakuan yang diberikan pada siklus I, maka diberikan tindakan pada siklus II dalam rangka memperbaiki pembelajaran pada materi turunan antara lain :

a) Pada pendahuluan (apersepsi), dosen mengingatkan kembali materi prasyarat yang harus disiapkan terkait soal - soal pada materi turunan.

b) Memperbanyak diskusi dalam kelompok, dimana peningkatan di harapkan meningkat pada level kelompok, dimana selanjutnya meingkat pada level individu 


\section{b. Siklus II}

Untuk mendapatkan Metode Pembelajaran inovasi pembelajaran yang diharapkan, dilakukan dengan proses penentuan nilai prestasi mahasiswa.

\section{1) Rencana Tindakan}

Tindakan khususnya dalam perencanaan pada PTK Siklus II sbb:

a) Pembuatan perangkat belajar berupa Rencana Pembelajaran Semester (RPS), RPP soal-soal evaluasi dan lembar observasi.

b) Koordinasi dengan Dosen lain yang bertindak sebagai pengamat (Observer) dalam proses pembelajaran

c) Menerapkan Metode Pembelajaran pembelaran dengan menggunakan media dengan sofwere komputasi matematika dan web oleh peneliti.

d) Melakukan evaluasi berupa tes tertulis untuk mengetahui kemampuan mahasiswa matakuliah matematika terapan materi integral.

\section{2) Pelaksanaan Kegiatan}

Pada siklus II wujud pelaksanaan tindakan pembelajaran yang telah $\begin{array}{llll}\text { direncanakan } & 7 & \text { (tujuh) kali }\end{array}$ pertemuan selama 2x50 Menit dan dilanjutkan dengan evaluasi 60 menit. Adapun tindakan dosen yang dilakukan adalah sebagai berikut :

a) Dosen memberikan apersepsi dan motivasi disetiap awal pertemuan serta mengingatkan akan hal - hal yang berkaitan dengan matakuliah yang akan diajarkan.

b) Dosen memberikan beberapa pertanyaan kepada mahasiswa dikelas untuk mengetahui pengetahuan awal mahasiswa mengenai matakuliah matematika terapan 2, kemudian menghubungkan dengan kehidupan sehari - hari dan membimbing mahasiswa untuk mengkontruksikannya.

c) Mahasiswa mendiskusikan hasil persoalan matematika terapan dalam kelompok yang telah ditentukan. Mereka secara bergantian menjelaskan alurnya, memberikan contoh soal beserta penyelesaiannya, dan kelompok yang lain menanggapi.

d) Mahasiswa menyelesaikan serta mendiskusikan Lembar Kerja yang diberikan oleh dosen, dan mengerjakan secara mandiri. Kemudian dosen memberikan bimbingan kepada mahasiswa jika menemukan kesulitan.

e) Dosen membimbing mahasiswa untuk menyimpulkan materi yang telah diperoleh pada setiap akhir pertemuan.

f) Pada pertemuan selanjutnya mahasiswa mengumpulkan hasil diskusi dan pemecahan masalahnya pada matakuliah matematika terapan 2.

g) Pada akhir siklus II dilakukan evaluasi untuk mengukur dan mengetahui kemampuan mahasiswa.

3) Observasi dan Evaluasi

Berdasarkan hasil pengolahan keaktifan mahasiswa dalam proses pembelajaran masih perlu dilakukan perbaikan terutama keberanian mengeluarkan pendapat, mengaitkan materi matakuliah matematika terapan 2 dengan kehidupan nyata. karena terdapat perbedaan kemampuan karakteristik diantara mahasiswa yang satu dengan yang lainnya. Motivasi dosen dalam membangkitkan motivasi perlu dikembangkan lagi. Selanjutnya keseluruhan aktifitas mahasiswa pada siklus I terekam pada lembar observasi dan nantinya akan menjadi catatan tersendiri bagi dosen didalam melakukan perbaikan dan inovasi pembelajaran. Hasil evaluasi siklus II memberikan kesimpulan tercapainya ketuntasan pada matakuliah matematika terapan materi integral. 
4) Refleksi

Berdasarkan hasil evaluasi mahasiswa pada proses siklus II yang mencapai ketuntasan, terlihat adanya modifikasi sehingga terdapat inovasi Metode Pembelajaran pembelajaran melalui bentuk soal latihan yang dikerjakan mahasiswa dapat meningkatkan kemampuan mahasiswa.

Terkait dengan ketuntasan mahasiswa pada siklus II ditemukan adanya faktor penerapan Metode Pembelajaran PBL yang di dukung dengan teknologi informasi dan komunikasi dapat meningkatkan kemampuan mahasiswa dalam menguraikan soal integral yang bersifat lebih dari satu proses.

Maka sebagai bentuk refleksi pada siklus II tersebut antara peneliti dan observer melakukan koordinasi dan sepakat menympulkan bahwa menerapkan media pembelajaran dan modul sebagai usaha khususnya terkait dengan soal bentuk terapan.

Berdasarkan hasil evaluasi dan observasi terhadap perlakuan yang diberikan pada siklus I, maka diberikan tindakan pada siklus II dalam rangka memperbaiki pembelajaran pada materi turunan antara lain :

a) Pada pendahuluan (apersepsi), dosen mengingatkan kembali materi prasyarat yang harus disiapkan terkait soal - soal pada materi turunan.

b) Penerapan media selain mempermudah dalam menyelesaikan permasalahan terkait denga integral, ini juga terbukti dapat meningkatkan motivasi belajar mahasiswa.

c) Dan bagi mahasiswa yang masih kategori sedang masih dilakukan bimbingan.

\section{Analisa Data}

Hasil analisa data dari pengambilan terhadap data prestasi, aktifitas, dan minat mahasiswa.

a. Prestasi Mahasiswa

Berdasarkan hasil berupa tes uraian (evaluasi), pada setiap siklus, diperoleh data yang dapat dilihat Tabel 1.

Tabel 1. Analisa Prestasi Mahasiswa

\begin{tabular}{lcc} 
Uraian & Siklus I & Siklus II \\
Nilai Tertinggi & 78 & 95 \\
Nilai terendah & 60 & 71 \\
Nilai rata - rata & 66,88 & 78,27 \\
Jumlah peserta tes & 25 & 25 \\
Jumlah mahasiwa tuntas & 14 & 25 \\
Jumlah mahasiswa belum tuntas & 11 & 0 \\
Prosentase Mahasiswa Tuntas & $56 \%$ & $100 \%$ \\
Prosentase mahasiswa belum tuntas & $44 \%$ & $0 \%$ \\
\hline
\end{tabular}

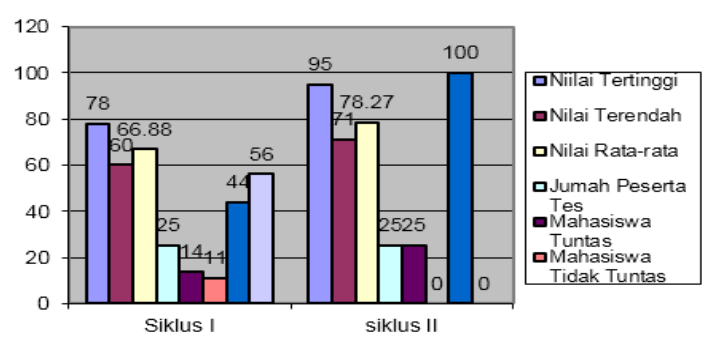

Gambar 1. Diagram Prestasi Mahasiswa b. Aktifitas Mahasiswa

Berdasarkan hasil pengamatan mahasiswa pada lembar observasi pada setiap siklus, diperoleh data yang dapat dilihat Tabel 2.

Tabel 2. Analisa Aktifitas Mahasiswa

\begin{tabular}{lll} 
Uraian & Siklus I & Siklus II \\
Tidak Aktif & 2 & 0 \\
Cukup Aktif & 16 & 6 \\
Aktif & 7 & 19 \\
\hline
\end{tabular}




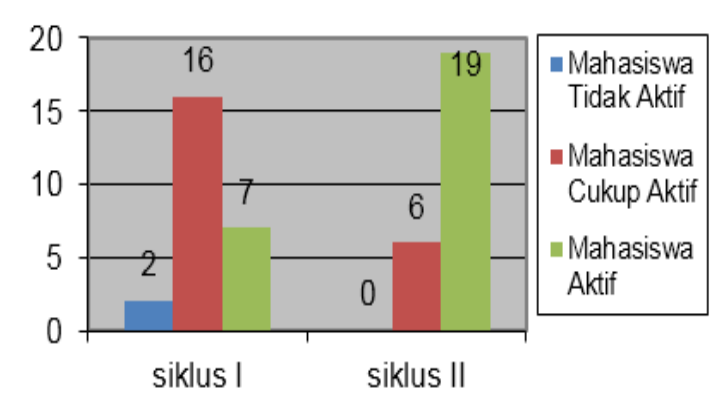

Gambar 2. Diagram Aktifitas Mahasiswa

\section{c. Minat}

Berdasarkan hasil Analisa terhadap angket yang telah diberikan kepada mahasiswa sebelum dan sesudah diberikan pembelajaran problem based learning terintegrasi TIK terlihat lengkap pada Tabel 3.

Tabel 3. Hasil Analisa Minat Mahasiswa

\begin{tabular}{ccc} 
Uraian & Sebelum & Sesudah \\
Mahasiswa Kurang Berminat & 16 & 0 \\
Mahasiswa Berminat & 3 & 21 \\
Mahasiswa sangat Berminat & 4 & 4 \\
\hline
\end{tabular}

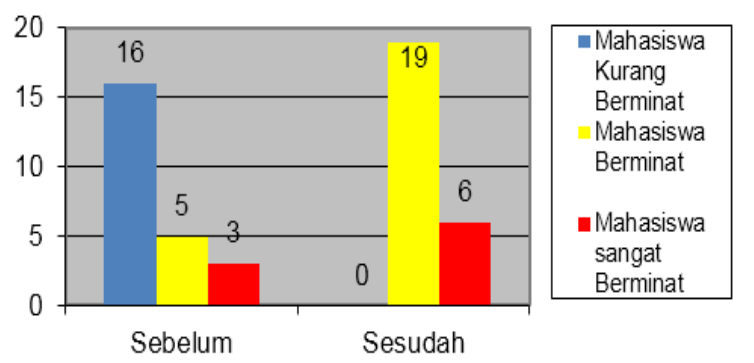

Gambar 3. Diagram Minat Mahasiswa

\section{d. Pembahasan}

Berdasarkan hasil Analisa data, maka diperoleh informasi bahwa hasil belajar mahasiswa semester 2A Prodi Teknik Mesin Tahun akademik 2017/2018 setelah diterapkan inovasi pembelajaran Metode Pembelajaran PBL nterintegrasi TIK dari setiap siklus dapat dijabarkan sebagai berikut :

\section{1) Prestasi Mahasiswa}

Hasil Analisa data pada siklus I materi matematika terapan 2 materi turunan, dari hasil evaluasi menunjukkan nilai rata-rata 66,88 dengan prosentase ketuntasan $56 \%$ ini menunjukkan belum tercapai target yang telah ditentukan, jadi nilai minimal adalah 70 dan ketuntasan hasil belajar $\geq 85 \%$. Dari hasil refleksi disimpulkan terdapat beberapa kesulitan yang dihadadpi oleh mahasiswa terkait evaluasi dalam bentuk soal penyelesaian turunan dengan definisi, dan soal turunan tingkat tinggi. Sehingga belum mencapai ketuntasan dan dilanjutkan siklus II dengan koordinasi dengan observer dosen dan memberlakukan media pembelajaran dengan teknologi informasi dan komunikasi dengan sofwere komputasi dan web lebih dominan.

Pada siklus II setelah dilakukan proses pembelajaran mahasiswa diberikan lembar kerja berisi soal - soal integral yang diselesaikan dengan cara kelompok dan individu, dimana di harapkan dengan peningkatan kemampuan mahasiswa di level kelompok nanti pada gilirannya dapat meningkatkan kemampuan individu masing - masing. Dan setelah dilakukan evaluasi pada siklus 2 diperoleh rata - rata nilai mahasiswa adalah 78,27 dengan prosentase ketuntasan 100\%. Hal ini menunjukkan peningkatan ketuntasan belajar adalah $78,54 \%$ dengan peningkatan rata - rata $17,03 \%$.

\section{2) Aktifitas Mahasiswa}

Pada aktifitas belajar mahasiswa dari siklus pertsama dan II mengalami perubahan semakin baik, dapat dilihat pada siklus pertama dari $36 \%$ pada siklus 
pertama meningkat menjadi $84 \%$ pada siklus II dan dapat ditarik kesimpulan mahasiswa aktif dalam proses pembelajaran. Beberapa hal yang menjadi pertimbangan dalam proses peningkatan aktifitas mahasiswa dimana komponen tersebut karena inovasi pembelajaran yang dilakukan oleh peneliti yaitu pada problem based learning dengan melihat hasil analisa aktifitas mahasiswa mampu meningkatkan kualitas aktifitas mahasiswa serta mempermudah dosen memberdayakan mahasiswa, mengetahui perbedaaan karakter mahasiswa, sehingga membuat suasana belajar kreatif, aktif dan menyenangkan, hal ini menjadi faktor utama dalam menciptakan pembelajaran yang efektif. Dengan adanya lembar kerja yang mengarahkan pada aplikasi mata kuliah matematika terapan 2 dalam kehidupan sehari - hari menjadi salah satu hal penting dalam memotivasi mahasiswa untuk meningkatkan rasa keingintahuan mereka dan sikap kritis mereka(Qurohman, 2017b). Kesadaran dalam menciptkan kelompok - kelompok belajar yang dibarengi dengan pemberian tugas dengan tujuan untuk mengkontruksi pemahaman mahasiswa terkait dengan matakuliah matematika terapan 2 dengan materi turunan dan integral. Kemudian pada tahap berikutnya mahasiswa akan berusaha mencapai tujuan belajar, mereka menggunakan pengalaman dan pengetahuan untuk membangun pengalaman yang dinamis. Kemampuan dosen dalam mengaitkan materi perkulihan dengan kehidupan nyata secara konstektual membantu mahasiswa untuk memahami matakuliah yang sedang dipelajarinya (Qurohman, 2017a).

\section{3) Minat Mahasiswa}

Dengan diterapkan metode inovasi pembelajaran problem based learning terintegrasi teknologi komunikasi dan informasi (TIK) pada matakuliah matematika terapan 2 , terlihat terdapat peningkatan minat. Hal ini disebabkan beberapa faktor diantaranya motivasi, lingkungan, pengalaman, pemahaman dan faktor dari Dosen itu sendiri, melalui penerapan pembelajaran problem based learning terintegrasi TIK mahasiswa merasakan setiap evaluasi dan pengalaman belajar sangat berharga, dan mereka benar - benar mengalaminya sendiri. Hal ini sesuai dengan komponen utama dari inovasi pembelajaran problem based learning dimana penilaian mengukur semua aspek pembelajaran seperti : kinerja, proses dan produk yang dikerjakan selama proses pembelajaran berlangsung (Baharun \& Adhimiy, 2018). Serta tugas - tugas yang diberikan mahasiswa dengan selalu mengedepankan pengalaman kehidupan sehari - hari yang selalu dikaitkan dengan mata pelajaran/matakuliah(Yadav, Subedi, Lundeberg, \& Bunting, 2011).

Secara umum peningkatan prestasi mahasiswa pada matakuliah matematika terapan 2 ini diikuti dengan peningkatan aktifitas dan minat mahasiswa. Sehingga dengan menerapkan pembelajaran problem based learning dalam matakuliah matematika terapan 2 dapat mengajak mahasiswa untuk berperan aktif dan melibatkan segenap kemampuan yang dimiliki oleh mahasiswa, sehingga pemhaman konsep dapat dapat diterima dengan baik. Dengan demikian pembelajaran Problem based learning terintegrasi TIK dapat diterapkan dan efektif pada matakuliah matematika terapan 2 .

Terdapat beberapa penelitian sebelumnya terkait dengan inovasi model pembelajaran yang dilakukan oleh para peneliti. (Masitoh \& Fitriyani, 2018) melakukan penelitian terkait yaitu Pengaruh Pembelajaran Problem Based Learning pada mahasiswa Program Studi Teknik Mesin. Dari hasil penelitian menyimpulkan bahwa keuntungan 
belajar mahasiswa dari PBL dua kali lipat dari pelajaran konvensional.

$\begin{array}{lcr}\text { Penelitian } & \text { terkait } & \text { juga } \\ \text { menyimpulkan } & \text { bahwa } & \text { multiple } \\ \text { intelligences } & \text { matematis } & \text { logis }\end{array}$

memberikan prestasi belajar sama baiknya dengan kategori multiple intelligences interpersonal pada peserta didik yang menggunakan model pembelajaran PBL (Fatimah, 2012). Artinya selain prestasi belajar juga dapat mendapat pengaruh yang baik ketika diberikan penerapan model pembelajaran PBL sama halnya dalam penelitian ini PBL dengan bantuan TIK dapat memberikan dampak yang baik terhadap peningkatan minat dan aktvitas belajar, yang secara tidak langsung dapat meningkatkan hasil belajar.

\section{SIMPULAN DAN SARAN}

Berdasarkan hasil penelitian dapat disimpulkan bahwa penerapan inovasi pembelajaran problem based learning yang terintegrasi dengan teknologi komunikasi dan informasi pada matakuliah matematika terapan 2 pada mahasiswa semester 2 politeknik harapan Bersama tegal tahun akademik 2017/2018 semester genap sebagai berikut : (1) Hasil sebaran kuisioner minat mahasiswa pada pembelajaran PBL terintegrasi TIK setelah diberi perlakuan dengan prosentase awal yang sebesar 22,87 \% meningkat menjadi 89,00 \% pada siklus II ; (2) Meningkatkan aktifitas belajar mahasiswa, hal ini dapat dilihat dari prosentase aktifitas mahasiswa di siklus I dengan tingkat prosentase $64 \%$ tergolong cukup aktif, dan pada siklus II sebesar $76 \%$ yang masukl kategori aktif; (3) Meningkatkan prestasi, aktifitas, dan minat belajar mahasiswa yang terlihat dari perolehan nilai rata - rata mahasiswa pada siklus I sebesar 66,88 dan dengan ketuntasan belajar mahasiswa 56\%. Nilai rata - rata mahasiswa di siklus II sebesar 78,27 dan ketuntasan belajar mahasiswa adalah $100 \%$.

\section{Saran}

Dalam memperoleh sebuah akurasi dengan tingkat akurasi yang lebih baik lagi, terdapat beberapa saran yang harsu dilakukan, sebagai berikut : (1) Metode Pembelajaran yang didapatkan perlu untuk di eksperimenkan dengan menggunakan berbagai dataset yang sesuai sehingga dapat dilihat performance dari Metode Pembelajaran tersebut; (2) Perlu dilakukan ekperimen percobaan Metode Pembelajaran lain untuk optimaliasi tingkat akurasi klasifikasi Tingkat Penguasaan Materi Bahan Ajar sebagai bagian dari evaluasi Metode Pembelajaran yang sudah didaptkan sebelumnya.

\section{DAFTAR PUSTAKA}

Akhmadi, A.N., Qurohman, M.T. and Syarifudin, S., 2017. Peningkatan Kompetensi Auto CAD Bagi Siswa SMK Ma'arif NU Talang Kabupaten Tegal.Jurnal Pengabdian Masyarakat Progresif Humanis Brainstorming, 1(1).

Baharun, H. and Adhimiy, S., 2018. Curriculum Development Through Creative Lesson Plan. Cendekia: Jurnal Kependidikan Dan Kemasyarakatan, 16(1), pp.41-62.

Fatimah, F., 2012. Kemampuan komunikasi matematis dan pemecahan masalah melalui problem based-learning. Jurnal Penelitian dan Evaluasi Pendidikan, 16(1), pp.249-259.

Fitriyadi, H., 2012. Keterampilan TIK Guru Produktif SMK di Kabupaten Hulu Sungai Utara dan Implementasinya dalam Pembelajaran.Jurnal Pendidikan Vokasi, 2(2). 
Hardhono, A.P., 2002. Potensi teknologi komunikasi dan informasi dalam mendukung penyelenggaraan pendidikan jarak jauh di Indonesia. dalam Jurnal Pendidikan Terbuka dan Jarak Jauh, 3(1).

Ismaniati, C., 2010. Penggunaan teknologi informasi dan komunikasi dalam peningkatan kualitas pembelajaran. Yogyakarta: Universitas Negeri Yogyakarta.

Masitoh, L.F. and Fitriyani, H., 2018. Improving students' mathematics self-efficacy through problem based learning. Malikussaleh Journal of Mathematics Learning (MJML), 1(1), pp.26-30.

Muhson, A., 2009. Peningkatan Minat Belajar dan Pemahaman Mahasiswa Melalui Penerapan Problem-Based Learning. Jurnal Kependidikan: Penelitian Inovasi Pembelajaran, 39(2).

Nasir, A.M. and Hasmar, D.H., 2018. Relation between student's perceptions to the statistics lecturer in learning process with statistics

achievement. Malikussaleh Journal of Mathematics Learning (MJML), 1(1), pp.9-12.

Nuraeni, N., Fitrajaya, A. and Setiawan, W., 2010. Efektivitas penerapan model pembelajaran generatif untuk meningkatkan pemahaman siswa dalam mata pelajaran teknologi informasi dan komunikasi. Makalah. Bandung: UPI-Bandung.

Qurohman, M.T., 2017. Meningkatkan Kemampuan Pemecahan Masalah Kalkulus Lanjut Melalui Pembelajaran Kooperatif Tipe CoOp Co-Op. Cakrawala: Jurnal Pendidikan, 11(1), pp.32-37.

Romadhon, S.A. and Qurohman, M.T., 2017. The Advantages of Youtube to Enhance Student's Vocabulary
In Mechanical Engineering Classroom. Wiralodra English Journal, 1(1), pp.14-20.

Sariningsih, R. and Purwasih, R., 2017. Pembelajaran Problem Based Learning Untuk Meningkatkan Kemampuan Pemecahan Masalah Matematis Dan Self Efficacy Mahasiswa Calon Guru. JNPM Uurnal Nasional Pendidikan Matematika), 1(1), pp.163-177.

Wulandari, N. and Damris, M., 2011. Pengaruh Problem Based Learning dan Kemampuan Berpikir Kritis Terhadap Hasil Belajar Mahasiswa. Jurnal TeknoPedagogi, 1(1).

Yadav, A., Subedi, D., Lundeberg, M.A. and Bunting, C.F., 2011. Problem-based learning: Influence on students' learning in an electrical engineering course. Journal of Engineering Education, 100(2), pp.253-280. 